\title{
Hubungan Pengetahuan Dengan Pelaksanaan Discharge Planning Di Ruang Rawat Inap RSUD Kota Dumai Riau
}

\author{
Rina Fitriani ${ }^{1 *}$, Hafni Bachtiar ${ }^{2}$, Esthika Ariany Maisa ${ }^{3}$ \\ ${ }^{1}$ Program Studi Magister Keperawatan Kekhususan Manajemen Keperawatan Universitas Andalas \\ ${ }^{2,3}$ Program Studi Magister Ilmu Keperawatan Universitas Andalas \\ *Correspondence email: rinafitriani1981@gmail.com
}

\begin{abstract}
Abstrak. Discharge planning merupakan suatu proses dimulai pasien menerima pelayanan kesehatan yang diikuti dengan kesinambungan perawatan baik dalam proses penyembuhan maupun dalam mempertahankan derajat kesehatan sampai pasien merasa siap untuk kembali kelingkungannya, dan juga merupakan salah satu bagian penting dari pelaksanaan asuhan keperawatan. Dengan adanya discharge planning dapat mengurangi hari /lama perawatan pasien, mencegah kekambuhan, meningkatkan kondisi kesehatan pasien dan menurunkan angka mortalitas dan morbilitas. Penelitian ini bertujuan untuk mengengetahui hubungan pengetahuan dengan pelaksanaan discharge planning diruang rawat inap RSUD Dumai. Desain penelitian ini adalah cross sectional dengan menggunakan uji Chi square. Sampel berjumlah 96 perawat pelaksana. Teknik sampel yang digunakan adalah Propotional Stratified Random Sampling. Hasil penelitian adalah sebagian besar perawat kurang baik dalam pelaksanaan discharge planning yaitu 72.9\%. sebagian besar pengetahuan perawat kurang baik yaitu $89.6 \%$. Hasil uji analisis menunjukan tidak ada hubungan yang signifikan antara faktor pengetahuan dengan pelaksanaan discharge planning $(\mathrm{p}=0.199)$.
\end{abstract}

Kata Kunci: Discharge Planning; Pengetahuan

Abstract. Discharge planning is a process that begins with the patient receiving health services followed by continuity of care both in the healing process and in maintaining the degree of health until the patient feels ready to return to his environment, and is also an important part of the implementation of nursing care. With the discharge planning can reduce the days / length of patient care, prevent recurrence, improve the patient's health condition and reduce mortality and morbidity. This study aims to determine the relationship between knowledge and the implementation of discharge planning in the inpatient room of Dumai Hospital. The design of this study was cross sectional using the Chi square test. The sample consisted of 96 nurses. The sample technique used is proportional stratified random sampling. The results showed that most of the nurses were not good at discharge planning, namely 72.9\%. Most of the nurses' knowledge was not good, namely $89.6 \%$. The results of the analysis test showed that there was no significant relationship between the knowledge factor and the implementation of discharge planning $(p=0.199)$.

Keywords: Discharge Planning, Knowledge

\section{PENDAHULUAN}

Discharge planning menurut Cawthorn (2005) merupakan pelayanan yang mempersiapkan pasien agar mendapatkan perawatan berkelanjutan, baik dalam proses penyembuhan maupun dalam menpertahankan derajat kesehatan sampai pasien siap kembali kelingkungan, dan menurut Kozier (2004) discharge planning adalah suatu proses dimulai pasien menerima pelayanan kesehatan yang diikuti dengan kesinambungan perawatan baik dalam proses penyembuhan maupun dalam mempertahankan derajat kesehatan sampai pasien merasa siap untuk kembali kelingkungannya.

Pelaksanaan discharge planning sangat penting bagi keberlangsungan perawatan kesehatan, dan menjadi suatu implementasi yang harus dilaksanakan oleh perawat dengan baik, namun dalam pelaksanaan discharge planning dirumah sakit berdasarkan penelitian di luar negeri, penelitian yang dilakukan Graham (2013) bahwa sebanyak $23 \%$ perawat di Sydney, Australia belum melaksanan discharge planning dengan baik karena kurangnya kepatuhan perawat, dan penelitian yang dilakukan Morris et al.(2012) bahwa sebanyak $34 \%$ perawat di Inggris tidak melakukan discharge planning dengan optimal dikarenakan kurangnya komunikasi perawat dan jumlah pegawai yang tidak memadai dan hubungan yang buruk dengan lembaga eksternal, serta berdasarkan penelitian yang dilakukan Gholizadeh (2015) di Iran menyatakan discharge planning belum menjadi prioritas dalam sistem kesehatan Iran karena tenaga kerja yang sedikit dan beban kerja yang banyak, dan penelitian yang dilakukan Toufighi et al. (2018) di Iran menyatakan bahwa ada kekurang patuhan pasien rawat jalan dan lama rawat inap dirumah sakit Roozbeh, sehingga perlunya pengembangan dan pelaksananan discharge planning yang menjadi hal utama sedangkan di Indonesia, penelitian yang dilakukan Zuhra (2016) di Yogyakarta bahwa $60 \%$ perawat melaksanakan discharge planning dengan kurang baik dikarenakan perawat hanya melakukan discharge planning di akhir dan hanya melakukan tindakan yang penting-penting saja tanpa memperhatikan secara detail dari tindakan discharge planning. Penelitian yang dilakukan Okatiranti (2015) di Bandung menunjukkan $54 \%$ perawat tidak melaksanakan discharge planning dengan baik 
dikarenakan kurangnya pengetahuan dan sikap perawat yang tidak mendukung pelaksanaan discharge planning, sedangkan penelitian yang dilakukan Rezkiki \& Fardilah (2019) di ruang rawat inap Embun Suri RSUD dr Achmad Mochtar Bukit Tinggi bahwa 50.3\% perawat tidak melaksakan discharge planning secara optimal dikarenakan perawat hanya melakukan tindakan yang penting-penting saja tanpa memperhatikan secara detail dari tindakan discharge planning. Dari beberapa hasil penelitian diatas membuktikan bahwa pelaksanaan discharge planning belum terlaksana dengan baik.

Menurut Potter\&Perry (2005) pemberi proses discharge planning harus dilakukan secara komprehensif dan melibatkan staf medis rumah sakit yang fungsinya sebagai konsultan. Perawat mempunyai posisi yang penting dalam proses perawatan pasien dan proses keperawatan dan sangat berpengaruh untuk memberikan pelayanan kontinuitas dengan discharge planning.

Menurut Standar Nasional Akreditasi Rumah Sakit (SNARS) Edisi I bahwa rumah sakit menetapkan regulasi pelaksanakan $\mathrm{p}$ discharge planning dari rumah sakit berdasarkan kondisi kesehatan pasien dan kebutuhan kesinambungan asuhan dan tindakan. Dokter penanggung jawab pelayanan (DPJP) dan profesional pemberi asuhan (PPA) lainnya bertanggung jawab atas asuhan pasien menentukan kesiapan pasien keluar rumah sakit berdasarkan atas kebijakan, kriteria dan indikasi rujukan yang ditetapkan rumah sakit, kebutuhan kesinambungan asuhan berarti rujukan ke dokter spesialis, rehabilitasi fisik, atau kebutuhan upaya preventif dirumah yang dikoordinasikan oleh keluarga pasien.

Menurut Potter \& Perry (2010) menyatakan idealnya discharge planning harus dilaksanakan oleh perawat secara terstruktur di mulai dari pengkajian saat pasien masuk kerumah sakit sampai pasien pulang dan menurut Carpenito, (2004) bahwa kesiapan pasien menghadapi pemulangan merupakan faktor penentu dari keberhasilan perawatan ketika berada dirumah dan setelah dirawat di rumah sakit. Sebelum pemulangan pasien dan keluarga harus mengetahui bagaimana cara memanajemen pemberian perawatan dirumah dan apa yang diharapkan didalam memantau masalah fisik yang berkelanjutan. Dan juga meningkatnya angka rawat ulang, dan pada akhirnya pasien menangung pembiayaan untuk biaya rawat inap dirumah sakit, hal ini di dukung dari penelitian yang dilakukan oleh Moore et al (2003) yang menunjukan $49 \%$ pasien kembali keklinik atau rumah sakit setelah dinyatakan pulang karena mempunyai masalah kesehatan, dan penelitian yang sama yang dilakukan oleh Fox et al.(2013) yang menyatakan terdapat hubungan yang bermakna antara discharge planning dengan penurunan angka rawat ulang pasien dalam satu sampai 12 bulan indeks pemulangan pasien di pelayanan kesehatan.

Pelaksanaan discharge planning yang tidak baik dapat dilihat dimana peran keperawatan terbatas pada kegiatan rutinitas yaitu hanya berupa inforrmasi kontrol ulang, sedangkan pasien memerlukan keperawatan kesehatan dirumah, konseling kesehatan atau penyuluhan dan pelayanan komunitas tetapi tidak dibantu dalam upaya memperoleh pelayanan sebelum pemulangan sehingga pasien sering kembali keruang kedaruratan dengan masalah minor, dan sering kali diterima kembali dalam waktu 24 jam sampai 48 jam dan kemudian di pulangkan kembali. Dan akibat kegagalan dalam memberikan dan mendokumentasikan discharge planning dapat beresiko terhadap beratnya penyakit, ancaman hidup, dan disfungsi fisik (Nursalam, 2016). Hal ini didukung oleh data dari Family Caregiver Alliance (2010) yang menunjukan bahwa akibat pelaksanaan discharge planning yang tidak baik, sebanyak $40 \%$ pasien mengalami lebih dari 65 kesalahan pengobatan setelah meninggalkan rumah sakit dan $18 \%$ pasien yang dipulangkan dari rumah sakit dirawat kembali dalam waktu 30 hari. Hal ini merupakan dampak dari pelaksanaan discharge planning yang tidak baik.

Pelaksanaan discharge planning dipengaruhi oleh faktor kinerja perawat. Menurut Gibson et al. (1997) ada tiga faktor yang mempengaruhi faktor kinerja yaitu (1) faktor individu; kemampuan, keterampilan, latar belakang (keluarga, pengalaman kerja, tingkat sosial) dan demografi (umur, etnis, jenis kelamin) seseorang, (2) faktor psikologis; persepsi, peran, sikap, kepribadian, motivasi dan kepuasan kerja dan (3) faktor organisasi; struktur organisasi, desain pekerjaan, kepemimpinan, sistem penghargaan (system reward).

Berdasarkan faktor individu dari hasil penelitian Okatiranti (2015) tentang karakteristik perawat menunjukkan bahwa sebanyak $62.9 \%$ perawat melaksanakan discharge planning pada rentang usia $\leq 35$ tahun (dewasa awal), sebanyak $40 \%$ perawat wanita melaksanakan discharge planning, sebanyak $40 \%$ perawat dengan pendidikan S1 melaksanakan discharge planning, sebanyak $67 \%$ perawat dengan status tidak menikah melaksanakan discharge planning, dan perawat dengan masa kerja $\leq 5$ tahun melaksanakan discharge planning. Pada penelitian yang dilakukan Sumah (2018) di RSUD DR.M.Halaussy Ambon yang menyatakan adanya hubungan pengetahuan perawat dengan pelaksanaan discharge planning, dimana pengetahuan perawat dan pelaksanaan discharge planning di RSUD DR. M. Halaussy Ambon baik yaitu 66.7\%, Penelitian yang dilakukan Frida \& Romanty (2020) di ruang rawat inap RS Martha Friska P.Brayan Medan yang menyatakan ada hubungan pengetahuan perawat dengan pelaksanaan discharge planning diruang rawat inap RS Martha Friska P.Brayan Medan dimana pengetahuan perawat baik sebanyak $50 \%$ dan pelaksanaan discharge planning cukup baik sebanyak $41.1 \%$.

RSUD Dumai merupakan rumah sakit milik pemerintah daerah yang telah ditetapkan sebagai rumah sakit tipe B berdasarkan Keputusan Kepala Dinas 
Penanam Modal Pelayanan Terpadu Satu Pintu Propinsi Riau No.503/ DPMPTSP/ IZIN-KES/07, RSUD Dumai mempunyai 9 ruang rawat inap yang diklasifikasikan dari kelas III sampai dengan VVIP, dengan jumlah perawat 154 perawat di ruang rawat inap.

Pelaksanaan discharge planning dapat menurunkan length of stay (LOS) yang merupakan indikator mutu pelayanan rawat inap di rumah sakit yang selalu dievaluasi sertap tahunnya. Indikator pelayanan rawat ianap di RSUD Dumai pada tahun 2019 yaitu BOR $76.58 \%$, LOS 4.08 hari, BTO 56.11 kali, TOI 1.52 hari, NDR $21.42 \%(<4.5 \%)$, GDR $36.88 \%$ (<2.5\%), berdasarkan standar depkes RI 2009 BOR RSUD Dumai sudah mencapai standar depkes yaitu 60-85\%. Nilai LOS RSUD Dumai masih dibawah standar depkes yaitu 6-9 hari, tetapi dianjurkan serendah mungkin tanpa mempengaruhi kualitas pelayanan keperawatan, nilai TOI RSUD Dumai sudah mencapai standar depkes yaitu 1-3 hari, nilai BTO RSUD Dumai tinggi dari nilai standar depkes yaitu 40-50 kali berarti jumlah tempat tidur dan kualitas pelayanan perawatan sudah mencapai standar depkes. Jumlah kunjungan rawat inap tahun 2019 yaitu 17.498 kunjungan dimana lebih rendah dari jumlah kunjungan tahun 2018 yaitu 19.124 kunjungan di karenakan adanya peraturan yang ketat dari BPJS. Berdasarkan data dari bidang pelayanan didapatkan hasil survey kepuasan pelanggan yang menunjukan nilai IKM (Indeks Kepuasan Masyarakat) RSUD Dumai tahun 2019 yaitu $77.32 \%$ (Baik).

RSUD Dumai sudah memiliki Standar Operasional Prosedur (SOP) discharge planning sesuai kebijakan Keputusan direktur No 015/KPTSDirektur/2016 dan format discharge planning, format discharge planning diisi oleh perawat di ruang rawat inap, DPJP mendokumentasikan discharge planning pasien pada resume medis dan menyiapkan surat kontrol serta surat keterangan sakit bila diperlukan. Discharge planning dilakukan oleh DPJP dan perawat di ruang rawat inap.

Survei awal yang dilakukan peneliti pada tanggal 09 Maret 2020 terhadap 10 (Sepuluh) orang perawat rawat inap RSUD Dumai, saat ditanya tentang pelaksanaan discharge planning, 6 (Enam) orang menyatakan bahwa discharge planning pada pasien tersebut hanya dilakukan untuk kelengkapan administratif pasien pulang serta dilakukan pada hari kepulangan pasien dan tidak dijelaskan secara rinci tentang hal-hal yang harus disampaikan pada pasien sehubungan dengan pelaksanaan discharge planning, perawat memberikan informasi tentang kesehatan pasien secara incidental. Promosi dan pendidikan kesehatan sebagai bagian dari discharge planning diberikan hanya pada saat keluarga pasien bertanya dan hanya didokumentasikan di form edukasi terintegrrasi, sebanyak 4 (Empat) orang perawat menyatakan tidak mengetahui bagaimana proses pelaksanaan discharge planning yang seharusnya. Dan 10 (Sepuluh) orang perawat yang diwawancara semuanya mengatakan belum pernah mendapatkan kesempatan untuk mengikuti pelatihan yang berhubungan dengan discharge planning.

Dan hasil studi dokumentasi pada 10 (Sepuluh) format discharge planning yang yang berisi hal-hal yang perlu diperhatikan pasien setelah pulang, sebanyak 50 $\%$ format discharge planning yang tidak diisi lengkap dan hanya ada tanda tangan perawat serta pasien atau keluarga, perawat hanya mengisi data dasar pasien, ini dikarenakan pada awal pasien dirawat perawat langsung meminta tanda tangan keluarga dan saat pasien pulang kadang perawat lupa melengkapi. Perawat sering tidak melakukan pendokumentasian setelah melakukan edukasi tentang pendidikan kesehatan hal ini disebabkan karena banyaknya kesibukan yang harus dikerjakan sehingga perawat sering lupa untuk mendokumentasikan. Kurangnya motivasi perawat dan pemahaman yang berbeda tentang pengisian formulir discharge planning walaupun sudah dilakukan sosialisasi. Penerapan discahrge planning di RSUD Dumai dilaksanakan dengan pendekatan SNAR edisi I.

Hasil wawancara peneliti tanggal 12 Maret 2020 dengan 5 (Lima) orang pasien yang akan pulang tentang pelaksanaan discharge planning menyatakan bahwa informasi yang telah didapatkannya adalah cara minum obat dan informasi kontrol ulang dan itu dilakukan secara verbal dan tidak didokumentasikan. Fenomena inilah yang menjadikan landasan untuk dilakukan penelitian Hubungan dengan pelaksanaan discharge planning di ruang rawat inap RSUD Dumai Riau.

\section{METODE}

Penelitian ini adalah penelitian cross sectional. Populasi dalam penelitian ini seluruh perawat pelaksana sebanyak 154 perawat pelaksana di ruang rawat inap dan sampel dalam penelitian ini berjumlah 96 responden. Pengambilan sampel dengan Propotional Stratified Random Sampling.

\section{HASIL DAN PEMBAHASAN}

\section{Analisis Univariat}

\section{Karakteristik Perawat RSUD Dumai}

Hasil analisis univariat katakteristik perawat RSUD Dumai yang meliputi Umur, jenis kelamin, status perkawinan, tingkat pendidikan dan lama kerja. dapat dilihat pada tabel 5.1.

Tabel 1. Distribusi Frekuensi Karakteristik Perawat Di Ruang Rawat Inap RSUD Dumai ( $\mathrm{n}=96)$

\begin{tabular}{lll}
\hline Variabel Karakteristik & Frekuensi & $\%$ \\
\hline Umur & & \\
Dewasa Awal & 67 & 69.8 \\
Dewasa Akhir & 29 & 30.2 \\
\hline Jenis Kelamin & & \\
Laki-laki & 9 & 9.4 \\
Perempuan & 87 & 90.6 \\
\hline
\end{tabular}


Rina Fitriani, Hafni Bachtiar dan Esthika Ariany Maisa, Hubungan Pengetahuan Dengan Pelaksanaan Discharge Planning Di Ruang Rawat Inap RSUD Kota Dumai Riau

\begin{tabular}{lll}
\hline Tingkat Pendidikan & & \\
DIII Keperawatan & 73 & 76,0 \\
Ners & 23 & 24,0 \\
\hline Status Perkawinan & & \\
Menikah & 79 & 82.3 \\
Tidak Menikah & 17 & 17.7 \\
\hline Lama Kerja & \\
$\leq 5$ tahun & 34 & 35.4 \\
$>5$ tahun & 62 & 64.6 \\
\hline
\end{tabular}

Dari tabel 1 dapat dilihat lebih dari separuh responden berada dalam rentang usia dewasa awal $(69.8 \%)$ dan hampir seluruhnya berjenis kelamin perempuan (90.6\%). sebagian besar responden memiliki tingkat pendidikan DIII keperawatan (76.0\%). Sebagian besar responden berstatus perkawinan menikah $(82.3 \%)$ serta lebih dari separuh responden memiliki masa kerja $>5$ tahun $(64,6 \%)$.

\section{Pelaksanaan Discharge Planning Berdasarkan Karakteristik Perawat}

Hasil analisis univariat pelaksanaan discharge planning berdasarkan karakteristik perawat dapat dilihat pada tabel 2 .

Tabel 2. Distribusi Frekuensi Pelaksanaan Discharge Planning Berdasarkan Karakteristik Perawat Di Ruang Rawat Inap

\begin{tabular}{|c|c|c|c|c|c|c|}
\hline \multirow{3}{*}{$\begin{array}{l}\text { Karakteristik } \\
\text { Perawat }\end{array}$} & \multicolumn{4}{|c|}{$\begin{array}{c}\text { Pelaksanaan Discharge } \\
\text { Planning }\end{array}$} & \multicolumn{2}{|c|}{ Total } \\
\hline & \multicolumn{2}{|c|}{ Baik } & \multicolumn{2}{|c|}{ Kurang Baik } & \multirow[b]{2}{*}{$\mathrm{f}$} & \multirow[b]{2}{*}{$\%$} \\
\hline & $\mathrm{f}$ & $\%$ & $\mathrm{f}$ & $\%$ & & \\
\hline \multicolumn{7}{|l|}{ Umur } \\
\hline Dewasa Awal & 18 & 26,9 & 49 & 73,1 & 67 & 100 \\
\hline Dewasa Akhir & 8 & 27,6 & 21 & 72,4 & 29 & 100 \\
\hline \multicolumn{7}{|l|}{ Jenis Kelamin } \\
\hline Laki-laki & 1 & 11,1 & 8 & 88,9 & 9 & 100 \\
\hline Perempuan & 25 & 28,7 & 62 & 71,3 & 87 & 100 \\
\hline \multicolumn{7}{|l|}{ Tingkat pendidikan } \\
\hline DIII Keperawatan & 18 & 24,7 & 55 & 75,3 & 73 & 100 \\
\hline Ners & 8 & 47,8 & 15 & 65,2 & 23 & 100 \\
\hline \multicolumn{7}{|l|}{ Status Perkawinan } \\
\hline Menikah & 22 & 27,8 & 57 & 72,2 & 79 & 100 \\
\hline Tidak Menikah & 4 & 23,5 & 13 & 76,5 & 17 & 100 \\
\hline \multicolumn{7}{|l|}{ Lama Kerja } \\
\hline$\leq 5$ tahun & 8 & 23,5 & 26 & 76,5 & 34 & 100 \\
\hline$>5$ tahun & 18 & 29,0 & 44 & 71,0 & 62 & 100 \\
\hline
\end{tabular}

Dari tabel 2 dapat dilihat dari semua karakteristik perawat baik umur, jenis kelamin, status perkawinan, tingkat pendidikan dan lama kerja, seluruh komponen karakteristik perawat sebagian besar kurang baik dalam melaksanakan discharge planning, namun dari minoritas yang melakukan discharge planning secara baik yaitu pada tingkat pendidikan Ners lebih baik dalam pelaksanaan discharge planning yaitu Ners $47,8 \%$ dan DIII keperawatan $24.7 \%$.

\section{Hubungan Pengetahuan dengan pelaksanaan discharge planning}

Hasil analisis univariat faktor yang berhubungan dengan pelaksanaan discharge planning yaitu pengetahuan, sikap dan motivasi dapat dilihat pada tabel 3.

Tabel 3. Distribusi Frekuensi Pengetahuan Dengan Pelaksanaan Discharge Planning Di Ruang Rawat Inap RSUD Dumai $(\mathrm{n}=96)$

\begin{tabular}{lll}
\hline Variabel Independen & Frekuensi & $\%$ \\
\hline Pengetahuan & & \\
Baik & 10 & 10,4 \\
Kurang Baik & 86 & 89,6 \\
\hline
\end{tabular}

Dari tabel 3 dapat dilihat sebagian besar responden memiliki pengetahuan yang kurang baik (89,6\%), lebih dari separuh responden memiliki sikap negatif $(52,1 \%)$ dan sebagian besar motivasi responden yang baik $(81,2 \%)$.

\section{Pelaksanaan Discharge Planning}

Hasil analisis univariat pelaksanaan discharge planning dapat dilihat pada tabel 4 .

Tabel 4. Distribusi Frekuensi Pelaksanaan Discharge Planning Di Ruang Rawat Inap RSUD Dumai ( $\mathrm{n}=96)$

\begin{tabular}{lll}
\hline Pelaksanaan Discharge Planning & Frekuensi & $\%$ \\
\hline Baik & 26 & 27,1 \\
Kurang Baik & 70 & 72,9 \\
\hline
\end{tabular}

Dari tabel 4 dapat dilihat sebagian besar responden berada pada kategori kurang baik dalam pelaksanaan discharge planning $(72,9 \%)$.

\section{Analisis Bivariat}

Analisis bivariat ini untuk melihat hubungan antara pengetahuan dengan pelaksanaan discharge planning di ruang rawat inap RSUD Dumai dan dapat dilihat pada tabel berikut:

Tabel 5. Distribusi Frekuensi Hubungan Pengetahuan Dengan Pelaksanaan Discharge Planning Di Ruang Rawat Inap RSUD Dumai $(n=96)$

\begin{tabular}{|c|c|c|c|c|c|c|c|}
\hline \multirow{3}{*}{ Pengetahuan } & \multicolumn{4}{|c|}{$\begin{array}{c}\text { Pelaksanaan } \\
\text { Discharge Planning }\end{array}$} & \multirow{2}{*}{\multicolumn{2}{|c|}{ Total }} & \multirow{3}{*}{$\begin{array}{c}\mathrm{P} \\
\text { value }\end{array}$} \\
\hline & \multicolumn{2}{|c|}{ Baik } & \multicolumn{2}{|c|}{$\begin{array}{c}\text { Kurang } \\
\text { Baik }\end{array}$} & & & \\
\hline & $\mathrm{f}$ & $\%$ & $\mathrm{f}$ & $\%$ & f & $\%$ & \\
\hline Baik & 1 & 10,0 & 9 & 90,0 & 10 & 100 & \multirow{2}{*}{0,199} \\
\hline Kurang Baik & 25 & 29,1 & 61 & 70,9 & 86 & 100 & \\
\hline
\end{tabular}

Berdasarkan tabel 5 dapat dilihat pengetahuan responden dalam melaksanakan discharge planning yang baik lebih tinggi pada pengetahuan yang kurang baik dari pada pengetahuan yang baik yaitu pengetahuan kurang baik $29,1 \%$ dan pengetahuan baik $10,0 \%$. Secara 
statistik tidak terdapat hubungan yang signifikan antara pengetahuan dengan pelaksanaan discharge planning (nilai $\mathrm{p}>0.05$ ).

\section{Pembahasan \\ Pembahasan Univariat \\ Pelaksanaan Discharge Planning}

Dari hasil telaah dokumen discharge planning yang dilakukan perawat di ruang rawat inap Rumah Sakit Umum Dumai di dapat hasil yang menyatakan pelaksanaan discharge planning sebagian besar perawat kurang baik $72,9 \%$ dalam pelaksanaan discharge planning. Hal ini sejalan dengan penelitian yang dilakukan Rezkiki\&Fardilah (2019) pelaksanaan discharge planning kurang baik $(50,3 \%)$ dan penelitian yang dilakukan Zuhra (2016) dimana pelaksanaan discharge planning kurang baik (60\%).

Menurut Kozier (2004) discharge planning adalah suatu proses dimulai pasien menerima pelayanan kesehatan yang diikuti dengan kesenambungan perawatan baik dalam proses penyembuhan maupun dalam mempertahankan derajat kesehatan sampai pasien merasa siap untuk kembali kelingkungannya.

Dalam proses pelaksanaan discharge planning, discharge planning dilaksanakan pada setiap pasien kelolaan mulai pasien masuk sampai pasien pulang, setiap pelaksanaan discharge planning dilengkapi dengan membuat resume keperawatan, pengisian lembar discharge planning, surat kontrol dan leaflet yang sesuai dengan diagnosa perawat. Menurut Potter\& Perry (2005) langkah discharge planning yaitu pengkajian, diagnosa keperawatan, perencanaan, implementasi, dan evaluasi, sedangkan berdasarkan SOP RSUD Dumai bahwa pelaksanaan discharge planning yang dilakukan perawat adalah melakukan pengkajian, memberikan pendidikan kesehatan dan mengisi format discharge planning dan serta mencatat evaluasi pasien pulang pada lembar asuhan keperawatan.

Berdasarkan pedoman telaah dokumen yang dilakukan pada 5 aspek yaitu pengkajian diagnosa keperawatan, intervensi, implementasi dan evaluasi, dan dari hasil telaah terhadap 5 aspek tersebut yang paling banyak tidak terisi lengkap adalah pada aspek pengkajian, intervensi dan implementasi serta evaluasi.

Pada aspek pengkajian yang paling tidak lengkap terisi yaitu pengkajian faktor lingkungan yang mengganggu perawatan diri pasien (100\%). Berdasarkan teori menurut Potter \& Perry (2005), menyatakn bahwa pengkajian lingkungan yaitu lingkungan tempat tinggal pasien yang berupa faktorfaktor yang mengganggu perawatan diri pasien (ukuran kamar, ukuran ruangan untuk pasien berjalan, falilitas kamar mandi) merupakan salah satu eleman yang pengkajian yang sangat penting.

Pada aspek intervensi juga yang tidak diisi dengan lengkap pada pendokumentasian METHOD (97.92\%). Berdasarkan teori menurut Timby (2009) bahwa perencanaan pulang pasien membutuhkan identifikasi kebutuhan spesifik pasien dan perawat berfokus pada kebutuhan terencana pengajaran untuk persiapan pulang pasien yaitu METHOD (Medication, Environment, Treatment, Health Teaching, out referrel dan Diet).

Pada aspek implementasi yang tidak lengkap disi pada dokumentasi informasi tentang sumber pelayanan kesehatan dimasyarakat kepada keluarga dan pasien (100\%) dan dokumentasi pendidikan kesehatan kepada keluarga dan pasien (100\%). Pada format discharge planning yang paling banyak tidak diisi lengkap yaitu dokumentasi mobilitas pasien saat pulang $(51.04 \%)$ dan hasil pemeriksaan yang dibawa pulang (69.79\%). Pada aspek evaluasi yang tidak diisi lengkap yaitu dokumentasi evaluasi pasien pulang dilembar asuhan keperawatan $(53,13 \%)$.

Berdasarkan analisis peneliti bahwa pelaksanaan discharge planning kurang baik di karenakan pelaksanaan masih tidak sesuai dengan SOP, dan format pengkajian belum sesuai dengan teori dimana belum adanya pengkajian yang mengkaji lingkungan dirumah serta diognosa keperawatan khusus untuk discharge planning belum tampak sehingga pada perencanaan belum terlihat, sedangkan pada pendidikan kesehatannya perawat hanya memberikan tentang perawatan, obatobatan, dan hanya dalam bentuk peragaan dan audio, leaflet sangat jarang, dan pada format discharge planning juga tidak lengkap disi serta kurangnya pengetahuan perawat tentang pelaksanaan discharge planning yang baik. Menurut undang-undang no 38 tahun 2014 tentang keperawatan menyatakan bahwa salah satu tugas perawat yaitu sebagai penyuluh dan konselor bagi klien, dan menurut Potter \& Perry (2010) salah satu peran perawat adalah sebagai educator, perawat mempunyai tanggung jawab utama untuk memberi instruksi pada pasien mengenai masalah kesehatan, hal-hal yang harus dihindari, penggunaan obat-obatan di rumah, jenis komplikasi, dan sumber bantuan yang tersedia.

Berdasarkan hasil penelitian, usia perawat pelaksana RSUD Dumai sebagian besar berusia dewasa awal (69,8\%). Hal sejalan dengan pendapat Rusdi (2009) yang dikutip dalam S.Tahalele (2016) yang menyatakan rata-rata umur perawat pelaksana 35.8 tahun, dimana perawat pelaksana berada pada tingkat usia produktif yang dapat menunjang untuk kinerja yang lebih baik dan secara teori umur ini tergolong umur produktif dengan kemampuan psikososial yang dapat dipertanggung jawabkan, dan Menurut Robbins (2006) bahwa usia mempengaruhi kinerja, hal ini didasari tiga alasan yaitu kinerja pegawai akan menurun dengan bertambahnya usia, realita usia pegawai semakin bertambah dan memasuki masa pensiun. Kedewasaan seseorang dapat dilihat dari usia seseorang yang merupakan faktor yang mempengaruhi kemampuan, pengetahuan, tanggung jawab dalam bertindak, berfikir serta mengambil keputusan, semakin tua usia pegawai maka semakin tinggi komitmen terhadap organisasi. 
Berdasarkan hasil penelitian, jenis kelamin perawat RSUD Dumai hampir seluruhnya berjenis kelamin perempuan $(90,6 \%)$. Menurut Robbins (2006) menyatakan tidak ada perbedaan yang konsisten antara perempuan dan laki-laki dalam kemampuan memecahkan masalah, keterampilan, analisis, dorongan kompititif, motivasi dan sosiabilitas atau kemampuan belajar. Namun studi psikologis menemukan bahwa wanita lebih mematuhi wewenang dan pria lebih agresif dan lebih besar kemungkinannya dari wanita dalam pengharapannya untuk sukses, sedangkan menurut Kurniadi (2013) bahwa perawat perempuan dalam memberikan asuhan keperawatan lebih teliti dan sabar dalam melakukan pekerjaan dibandingkan pria karena psikologi perempuan membuat pekerja perempuan memberikan asuhan yang empati kepada pasien dibanding pria. Menurut Setiyaningsih (2013) dikutip S.Tahale (2016) yang menyatakan dunia keperawatan identik dengan ibu/wanita yang lebih dikenal dengan Mother Instinc, sehingga untuk mencari perawat yang berjenis kelamin laki-laki sangatlah terbatas, ditambah lagi output perawat yang dihasilkan dari perguruan tinggi yang rata-rata lebih banyak wanita dibandingkan laki-laki.

Berdasarkan hasil penelitian, tingkat pendidikan perawat RSUD Dumai sebagian besar DIII Keperawatan $(76,0 \%)$ berbanding dengan yang berpendidikan Ners (24\%). Menurut Robbins (2006) bahwa individu dengan tingkat pendidikan yang tinggi mampu bekerja dengan tingkat kesulitan dan tanggung jawab yang tinggi. Pendidikan dan pelatihan merupakan salah satu bagian terpenting dalam pengembangan staf (Marquis, B.L \& Huston, 2010). Pendidikan dan pelatihan yang diikuti perawat diharapkan dapat meningkatkan kemampuan seseorang perawat baik dalam pengetahuan, keterampilan maupun sikap (Notoatmodjo, 2012).

Berdasarkan hasil penelitian, status perkawinan perawat di RSUD Dumai sebagian besar dengan status sudah menikah (82,3\%). Menurut Robbins (2006) bahwa perkawinan membuat karyawan memaksakan peningkatan tanggung jawab yang dapat membuat suatu pekerjaan yang tetap menjadi lebih berharga dan penting. Perkawinan akan memotivasi sesorang untuk meningkatkan kinerja dengan cara meningkatkan hasil kerja baik secara kualitas maupun kuantitas dan melaksanakan tugas sesuai dengan tanggung jawabnya.

Berdasarkan hasil penelitian, lama kerja perawat RSUD Dumai lebih dari separuh lama kerja $\geq 5$ tahun (64,6\%). Menurut Kreitner dan Kinicki (2004) mengatakan masa kerja yang lama akan cenderung seorang pegawai lebih merasa betah dalam suatu organisasi, hal ini disebabkan karena telah beradaptasi dengan lingkungannya yang cukup lama sehingga seorang pegawai akan merasa nyaman dengan pekerjaannya. Dan menurut Siagian (2009) yang menyatakan lama kerja mempengaruhi pengalaman dan produktivitas, semakin lama kerja semakin banyak pengalaman dan produktivitas meningkat.

\section{Faktor Pengetahuan Perawat}

Berdasarkan hasil penelitian didapat faktor pengetahuan perawat sebagian besar kurang baik $(89,6 \%)$. Berbeda denga penelitian yang dilakukan Sumah (2018) dimana pengetahuan perawat baik (66.7\%) dalam pelaksanaan discharge planning. Pengetahuan merupakan hasil dari tahu dan terjadi setelah seseorang melakukan peinderaan terhadap objek tertentu. Pengetahuan merupakan domain yang sangat penting untuk terbentuknya tindakan seseorang (Priyoto 2014), dan menurut Notoadmojo ( 2007) pengetahuan dipengaruhi oleh beberpa faktor yaitu pendidikan, usia, minat, pengalaman, budaya dan paparan informasi.

Berdasarkan hasil kuesioner pengetahuan didapatkan pertanyaan yang paling banyak salah dijawab perawat yaitu mengenai prinsip dalam pelaksanaan discharge planning (79\%).

\section{Pembahasan Bivariat \\ Hubungan pengetahuan dengan pelaksanaan discharge planning}

Berdasarkan penelitian ini bahwa sebagian besar perawat di RSUD Dumai memiliki pengetahuan yang kurang baik sebanyak 86 orang $(89.6 \%)$ dalam yang memiliki pengetahuan baik $10(10.4 \%)$ dan yang mempunyai pengetahuan baik yang melaksanakan discharge planning dengan baik sebanyak 1 orang (10.0\%). Hasil uji analisis chi square diperoleh nilai $\mathrm{p}$ value sebesar $0.199 \quad(\mathrm{p}>0.05)$ maka dapat ditarik kesimpulan bahwa tidak ada hubungan antara pengetahuan perawat dengan pelaksanaan discharge planning di RSUD Dumai.penelitian ini sejalan dengan penelitan yang dilakukan oleh Octaviani, (2015) tentang hubungan antaran pengetahuan perawat dengan pelaksanaan discharge planning di ruang rawat inap RS Dustira Tk. II Cimahi diperoleh 25 perawat memiliki pengetahuan yang baik sebanyak $64.0 \%$ memiliki pelaksanan discharge planning yang baik, dan 40 perawat yang memiliki pengetahuan cukup sebanyak $35.0 \%$ memiliki pelaksanaan discharge planning yang buruk. Hasil uji statistik didapat nilai $\mathrm{p}$ value $=1.000(\mathrm{p}$ $>0.05$ ) maka disimpulkan tidak ada hubungan yang signifikan antara pengetahuan perawat dengan pelaksanaan discharge planning di ruang rawat inap RS Dustira Tk. II Cimahi. Hal ini juga sejalan dengan penelitian yang dilakukan Bhute et al., (2020) tentang Hubungan pengetahuan dan sikap perawat dengan pelaksanaan discharge planning pasien di RSUD Prof . DR. W.Z. Johannes Kupang di peroleh perawar sebagian besat memiliki pengetahuan yang baik sebanyak 20 orang $(50 \%)$ dan perawat yang memiliki pengetahuan baik yang melaksanakan discharge planning dengan baik sebanyak 6 organg (15\%) dan hasil uji analisis didapakan nilai $\mathrm{p}$ value $=0.057(\mathrm{p}>0.05)$ maka 
disimpulkan tidak ada hubungan yang signifikan antara pengetahuan perawat dengan pelaksanaan discharge planning di RSUD Prof. DR. W.Z. Jhohannes Kupang. Berbeda dengan penelitian yang dilakukan Sumah (2018) yang menunjukan ada hubungan pengetahuan perawat dengan pelaksanaan discharge planning, dan penelitian yang dilakukan Frida \& Romanti L (2020) juga menyatakan ada hubungan pengetahuan perawat dengan pelaksanaan discharge planning.

Berdasarkan penelitian Yulaita, 2011 di kutip dalam Octaviani, (2015) faktor yang dapat mempengaruhi pelaksanaan discharge planning yaitu motivasi, supervisi (pengawasan), fasilitas, beban kerja dan pengetahuan. Pengetahuan yang baik tidak tidak menjamin perawat RSUD Dumai dapat memberikan pelaksanaan discharge planning yang baik, karena perawat mempunyai peran yang penting dalam pelaksanaan discharge planning, sedangkan pelaksanaan discharge planning memerlukan pengetahuan yang baik sehingga apa yang disampaikan dapat dimengerti dan berguna untuk proses perawatan dirumah (Nursalam, 2009). Pengetahuan dipengaruhi oleh beberapa faktor yaitu pendidikan, umur, minat, dan pengalaman, kebudayaan dan informasi, dan salah satu faktor yang dapat meningkatkan produktifitas atau kinerja perawat dalam pelaksanaan discharge planning adalah pendidikan formal perawat.

Berdasarkan analisis pada penelitian ini pengetahuan tidak ada hubungan dengan pelaksanaan discharge planning di RSUD Dumai. Pada umumnya perawat yang memiliki pengetahuan discharge planning yang baik tidak menjamin pelaksanaan discharge planning yang baik pula atau sebaliknya perawat yang memiliki pengetahuan kurang cenderung memiliki pelaksanaan dischagr planning yang kurang baik. Hal ini menurut peneliti dikarenakan pengawasan yang kurang, serta mengacu pada fasilitas yang ada dan sikap seseorang walaupun mempunyai pendidikan yang rendah akan tetapi ditunjang dengan pengalaman yang baik akan menumbuhkan pelaksanaan yang positif. Peneliti berpendapat bahwa tidak ada hubungan antara pengetahuan dengan pelaksanaan discharge planning juga disebabkan karena perawat di RSUD Dumai sebagian besar berpendidikan DIII Keperawatan dan sebagian besar perwat RSUD Dumai masa kerja yang yang lebih dari 5 tahun, menurut Notoadmojo (2007) pengetahuan dipengaruhi oleh beberpa faktor yaitu pendidikan, usia, minat, pengalaman, budaya dan paparan informasi, menurut Siagian (2009) yang menyatakan lama kerja mempengaruhi pengalaman dan produktivitas, semakin lama kerja semakin banyak pengalaman dan produktivitas meningkat., dan menurut penelitian (Pribadi et al., 2019) pendidikan memberikan pengetahuan bukan saja yang langsung dengan pelaksanaan tugas tetapi juga landasan untuk mengembangkan diri serta kemampuan memanfaatkan semua sarana yang ada disekitar kita untuk kelancaran tugas. Pengetahuan yang cukup bisa menjamin perawat di rumah sakit dapat memberikan discharge planning dengan baik karena perawat mempunyai peran yang penting dalam discharge planning pasien. Menurut Notoadmojo (2007) menyatakan bahwa semakin tinggi pendidikan seseorang semakin mudah pula mereka menerima informasi, dan pada akhirnya makin banyak pula pengetahuan yang dimilikinya.

\section{SIMPULAN}

1. Karakteristik perawat di ruang rawat inap Rumah Sakit Umum Daerah Dumai yaitu lebih dari separuh berada pada umur dewasa awal, jenis kelamin hampir seluruhnya perempuan, tingkat pendidikan sebagian besar berpendidikan DIII keperawatan, status perkawinan sebagian besar perawat berstatus menikah, dan lebih dari separuh bekerja $>5$ tahun.

2. Sebagian besar perawat di ruang rawat inap RSUD Dumai memiliki kategori kurang baik dalam pelaksanaan discharge planning.

3. Sebagian besar perawat diruang rawat inap RSUD Dumai memiliki pengetahuan yang kurang baik dalam pelaksanaan discharge planning.

4. Tidak terdapat hubungan pengetahuan perawat dengan pelaksanaan discharge planning di ruang rawat inap RSUD Dumai.

\section{DAFTAR PUSTAKA}

Agung Prihantoro, SE., M. M. (2019). Peningkatan Kinerja Sumber Daya Manusia Melalui Motivasi, Disiplin Lingkungan Kerja Dan Komitmen. Deepublish.

Amin, M. Al, \& Juniati, D. (2017). Klasifikasi Kelompok Umur Manusia Berdasarkan Analisis Dimensi Fraktal Box Counting Dari Citra Wajah Dengan Deteksi Tepi Canny. Jurnal Ilmiah Matematika (MATHunesa), 2(6), 1-10.

Arikunto, P. D. S. (2010). Prosedur Penelitian Suatu Pendekatan Praktik. Rineka Cipta.

Arikunto, S. (2006). Prosedur Penelitian Suatu Pendekatan Praktik. Rineka Cipta.

Bhute, B., Ina Debora Ratu Ludji, \& Pius Weraman. (2020). Hubungan Pengetahuan Dan Sikap Perawat Dengan Pelaksanaan Discharge Planning Pasien Di Rsud Prof. Dr. W.Z. Johannes Kupang. Jurnal Pangan Gizi Dan Kesehatan, 9(1), 974989. https://doi.org/10.51556/ejpazih.v9i1.51

Carpenito, L., J. \& M. (2004). Nursing Care plans \& Documentation Nursing Diagnose and Collaborative (Fourth (ed.)). Elseiver Mosby.

Carpenito Lynda juall. (1999). Rencana Asuhan Keperawatan dan Dokumentasi Keperawatan (Edisi 2). EGC.

Cawthorn, L. (2005). Discharge Planning under the Umbrella of Advanced Nursing Practice Case Manager. Nursing Leadership, 18(4), 0-0. https://doi.org/10.12927/cjnl.2005.19033 
Dahlan, S. (2010). Statistik Untuk Kedokteran dan Kesehatan. Salemba Medika.

Efa Nur Aini, Andika Siswoaribowo, yuli N. (2018). Faktor-Faktor Yang Berhubungan Pelaksanaan Discharge Planning Di Instalasi Rawat Inap Bedah Rsud Dr Iskak Tulungagung.

family Caregiver Alliance. (2010). Hospital Discharge Planning: A Guide for Families and Caregivers. In Family CaregiversAlliance. http://www.caregiver.org/caregiver/jsp/content_no de.jsp?nodeid $=2312$

Fox, M. T., Persaud, M., Maimets, I., Brooks, D., Brien, K. O., \& Tregunno, D. (2013). Effectiveness of early discharge planning in acutely ill or injured hospitalized older adults : a systematic review and meta-analysis. BMC Geriatic, 1-9.

Frida, E. M., \& Romanty, L. (2020). Hubungan Pengetahuan Perawat Dengan Pelaksanaan Perencanaan Pulang Di Ruang Rawat Inap Rs Martha Friska

BrayanMedan.JurnalDarmaagung, 7.

https://jurnal.darmaagung.ac.id/index.php/darmaa gunghusada/article/view/718/621

Gholizadeh, M. (2015). Challenges in Patient Discharge Planning in the Heaith Systenm of iran: A Qualitative Study. Global Journal of Health Science, $168-178$. https://doi.org/10.5539/gjhs.v8n6p168

Gibson, J. L., Ivancevich, J. M., \& Jr, J. H. D. (1997). Organisasi: Perilaku, Struktur, Proses Jilid 2 (Djarkasih (ed.)). Erlangga.

Handoko, T. H. (2001). Manajemen Personalia dan sumber daya Manisia (Kedua). BPFE.

Hardivianty, C. (2017). Evaluasi Pelaksanaan Discharge Planning di Rumah Sakit PKU Muhammadiyah Gamping Yokyakarta (Evaluation of Discharge Planning in PKU Muhammaditah Hospital Gamping Yogyakarta). Proceeding Health Architecture, 1(1), 21-34. http://mmr.umy.ac.id/wpcontent/uploads/2017/05/Cynthia-

Hardivianty_Page-21-34.pdf

Jane Graham, R. G. and janine B. (2013). Nurses Discharge Planning And Risk Assesment; behaviours Understanding and Barriers. Journal of Clinical Nursing.

Junaidi, R. A. S. (2017). Analisis Pelaksanaan Discharge Planning dan Faktor-Faktor Determinan Pada Perawat di Ruang Rawat Inap RSUD Jambak Kabupaten Pasaman Barat Tahun 2017. Journal of Chemical Information anModeling,53(9),16891699.

https://doi.org/10.1017/CBO9781107415324.004

KARS. (2017). Akses Ke Rumah Sakit Dan Kontinuitas Pelayanan (ARK).

KARS. (2017). Standar Nasional Akreditasi Rumah Sakit Edisi 1,
Khalidawati, H. K. (2016). Prilaku Perawat Tentang Discharge Planneng di RSUD dr Zainoel Abidin Aceh.

Kholid Rosyidi MN, S.Kep, N. (2013). Manajemen Kepemimpinan Dalam Keperawatan. Trans Info Media.

Kozier \& Erb's. (2004). Fundamentals of Nursing: Consepts, Procces, and Practice (7th ed.). Prentice-Hall.

Kurniadi A. (2013). Manajemen Keperawatan dan Prospektifnya. FKUI.

Marquis, B.L \& Huston, C. . (2010). Kepemimpinan dan Manajemen Keperawatan: Teori dan Praktik (W. dan Handayani (ed.); Edisi 4, Vol. 27, Issue 3). EGC.

Moore, C., Wisnivesky, J., Williams, S., \& McGinn, T. (2003). Medical errors related to discontinuity of care from an inpatient to an outpatient setting. Journal of General Internal Medicine, 18(8), 646651. https://doi.org/10.1046/j.15251497.2003.20722.x

Morris, J., Winfield, L., \& Young, K. (2012). Registered nurses 'perceptions of the discharge planning process for adult patients in an acute hospital. Journal of Nursing Education and Practice, 2(1), 28-38. https://doi.org/10.5430/jnep.v2n1p28

Muhdim. Surati, H. S. (2016). Pengaruh Promosi Terhadap Pengetahuan Produk Dan Loyalitas Konsumen Pada unit Usaha Syariah PT Banl NTB. Jurnal Magister Manajemen Universitas Mataram, 5(4).

Nitisemito, A. S. (1996). Manajemen dan Sumber Daya Manusia. BPFE.

Nursalam, D. (2011). Manajemen Keperawatan Aplikasi dalam Praktek Keperawatan Profesional (A. Suslia (ed.); 3rd ed.). Selemba Medika.

Nursalam, P. D. (2014). Manajemen Keperawatan Apklikasi Dalam Praktek Keperawatan Profesional (A. Suslia (ed.); 4th ed.). Salemba Medika.

Nursalam, P. D. (2016). Manajemen Keperawatan Aplikasi dalam Praktik Keperawatan Profesional (P. P. Lestari (ed.); 5th ed.). Salemba Merdeka.

Nuryani, D. (2014). Pengetahuan Dan Sikap Perawat Terhadap Kelengkapan Pendokumentasian Asuhan Keperawatan Di Rumah Sakit H. 1-9.

Octaviani Kiki Rizki, D. D. (2015a). Hubungan Antara Pengetahuan Perawat Dengan Pelaksanaan Discharge Planning di Ruang Rawat Inap Rumah Sakit Tk II Cimahi. Jurnal Ilmu Keperawatan, 2 (2)(2), 49-59.

Octaviani Kiki Rizki, D. D. (2015b). Hubungan Antara Pengetahuan Perawat Dengan Pelaksanaan Discharge Planning Ruang Rawat Rumah Sakit Tk II Dustira Cimahi. Jurnal Ilmu Keperawatan, 2 (2).

Okatiranti. (2015). Gambaran pengetahuan dan sikap perawat dalam pelaksanaan discharge planning 
pada pasien diabetes mellitus type II. Jurnal Ilmu Keperawatan, III(1), 18-24.

Patricia A. Potter, A. G. P. (2010). Fundamental Keperawatan ( dr. A. F. Nggie (ed.); 7th ed.). Salemba Medika.

Pemerintah Republik Indonesia. (2014). UU No. 38 tentang Keperawatan (pp. 1-32).

Pemila,U. (2009). Konsep Discharge Planning. http://www.fik.ui.ac.id/pkko/files/

Potter, Patricia A.; Perry, A. G. (2005). Fundamental Keperawatan Konsep, Proses dan Praktik (R. Komalasari (ed.); 4 Vol 2). EGC.

Pribadi, T., Gunawan, M. R., \& Djamaludin, D. (2019). Hubungan Pengetahuan Dan Komunikasi Perawat Dengan Pelaksanaan Perencanaan Pulang Di Ruang Rawat Inap Rsud Zainal Abidin Pagaralam Way Kanan. Malahayati Nursing Journal, 1(1). https://doi.org/10.33024/manuju.v1i1.836

Prof. Dr.Soekidjo Notoatmodjo. (2012). Metodologi Penelitian Kesehatan. Rineka Cipta.

Prof.Dr.Sugiyono. (2010). Metode Penelitian Kuantitatif Kualitatif Dan R\&D. Alfabeta.

Rezkiki, F., \& Fardilah., V. N. (2019). Deskripsi Pelaksanaan Discharge Planning Di ruang Rawat Inap. Real In Nursing Journal, 2(3), 1-8.

Robbins, S. P. (2006). Prilaku Organisasi. PT. Indeks Kelompok Gramedia.

Sartika, E., Maulana, M. A., Rachmadi, F., Program, M., Keperawatan, S., Kedokteran, F., Tanjungpura, U., Keperawatan, D., Pelayanan, U., Paru-Paru, K., \& Pontianak, K. (2017). Faktor-Faktor Yang Mempengaruhi Pendokumentasian Asuhan Keperawatan Di Ruang Rawat Inap Rumah Sakit Universitas Tanjungpura Pontianak Factors That Influence the Documentation of Nursing Care in the Inpatient Room of Tanjungpura University Hospital Pontian. 437.

Selfince Tahalele, Mulyadi, R. S. H. (2016). Hubungan Antara Faktor Personil Perencanaan Pulang Dengan Kelengkapan Resume Medis Pasien Di Rumah Sakit Umum Daerah Maba Kabupaten Halmahera Timur. Jurnal Keperawatan, 4(1).

Siagian, S. P. (2009). Manajemen Sumber Daya Manusia Cetakan 17. Bumi Aksara.

Siregar, D. (2019). Kuesioner Pengetahuan Perawat Terhadap Discharge Planning Di Rumah Sakit Umum Daerah Sibuhuan (pp. 6-8).

Sumah, D. F. (2018). Hubungan Pengetahuan Perawat Dengan Pelaksanaan Discharge Planning Di Rsud Dr. M. Haulussy Ambon. Real In Nursing Journalsearchgate. https://doi.org/10.31227/osf.io/3c7gf

Timby, B. K. (2009). Fundamental Nursing Skills and Concepts. 969. http://books.google.com/books?id=M4HwH5IxfT oC\&pgis $=1$
Toufighi, H., Sharifi, V., Alaghband Rad, J., \& Shadloo, B. (2018). Development and Implementation of Discharge Planning Service in Roozbeh Hospital. Iranian Journal of Psychiatry and Clinical Psychology, 24(1), 56-69. https://doi.org/10.29252/nirp.ijpcp.24.1.56

Zuhra, P. (2016). Gambaran Pelaksanaan Discharge Planning Pasien Pasca operasi Appendiktomidi RSU Muhamaddiyah Gamping Yogyakarta. Ммит. 